\title{
Estudos semióticos: análise perceptiva e a terceiridade peirceana na obra "Jogos Infantis" de Pieter Bruegel
}

Semiotic studies: perceptual analysis and peircean thirdness

- the "Children's Games" by the artist Pieter Bruegel

\author{
NETTO, Marinilse, Universidade Federal de Santa Catarina I UFSC \\ mari.netto@hotmail.com
}

PERASSI, Richard, Doutor, Universidade Federal de Santa Catarina I UFSC

perassi@cce.ufsc.br

FIALHO, Francisco Antonio Pereira, Doutor, Universidade

Federal de Santa Catarina I UFSC

fapfialho@gmail.com

\section{Resumo}

Este trabalho propõe uma leitura semiótica da obra "Jogos Infantis" (1560) do artista Pieter Bruegel (1525-1569). A teoria de análise adotada corresponde à Semiótica Americana. A revisão de literatura sobre leitura de imagem, com base nos estudos da teoria Gestalt e nos Fundamentos da Linguagem e do Alfabetismo Visual, demonstram os aspectos estéticoexpressivos da imagem em estudo. Busca-se analisar a imagem da obra como processo de significação ou semiose.

Palavras Chave: Leitura de Imagem. Pieter Bruegel. Semiótica.

\section{Abstract}

This paper proposes a semiotic reading of the book "Children's Games" (1560) by the artist Pieter Bruegel (1525-1569). The theory of analysis adopted corresponds to American Semiotics, The literature review on image reading, based on studies of Gestalt theory and the Foundations of Language and Visual Literacy, demonstrate the aesthetic and expressive aspects of the image under study. The aim is to analyze the work's image as a process of signification or semiosis.

Keywords: Reading Image. Pieter Bruegel. Semiotics. 


\section{INTRODUC̣̃̃O}

O filósofo São Tomás de Aquino (1225-74) escreveu: "há no céu uma espécie de fonte luminosa que transmite imagens ideais, formadas segundo a vontade de Deus". ${ }^{4}$ Tal fenômeno parece ter sido também para Michelângelo Buonarroti (1475-1564) fonte de inspiração, pois, vejamos um trecho de um poema do artista: "Qualquer coisa bela na terra que seja vista/ao encontrar o forte e perceptivo olho/a semelhança a aquela fonte divina e de tudo que vier/é assim que captamos um pouco do céu". ${ }^{6}$

Voltando ao pensamento de S. Tomás de Aquino, Hugon (1998, p. 89) ao explicar o movimento da consciência humana entre sensação e concepção, diz: "o que cai imediatamente no alcance do saber humano é composto de matéria e forma, e o homem se eleva do composto ao simples, do posterior ao anterior". Em sua obra, postula que o conhecimento humano se dá pelo sensível e pelo intelectual, todavia, o conhecimento intelectual se dá pela visão da natureza das coisas, "a experiência e o raciocínio reclamam um outro princípio substancial, formal e dinâmico, para explicar a unidade, a fixação, a atividade dos viventes" (HUGON,1998, p.92).

Desse modo, para Aquino o conhecimento sensível é aquele que resulta da ação dos objetos materiais sobre os sentidos. Neste domínio, sua tese distingue dois conjuntos de potências: os sentidos externos, que são imediatamente afetados pelos objetos sensíveis, que, para serem percebidos, devem estar materializados e os sentidos internos que recebem seu conhecimento apenas por intermédio dos sentidos externos; conservam sua materialidade e podem reproduzi-los mesmo quando não há mais sensação.

Não é aqui o lugar de serem examinadas as diversas teses do pensamento de Aquino. Esse breve percurso tem como propósito ilustrar a "camada estratigráfica mais profunda da vida humana" (FRANCO Jr., 2001, p.190), a mentalidade da era medieval, contexto da obra de Pieter Bruegel. Um período em que o pensamento cristão exerceu massiva influência nas concepções filosóficas de mundo e da vida, "aceitando a existência de uma unidade cosmológica, o homem medieval via todas as coisas ligadas entre si" e tendo a fé como representação e fonte mais elevada das verdades reveladas, buscava

$4 \quad$ Calvino, Italo. Seis propostas para o próximo milênio. São Paulo: Cia das Letras, 1990, p.98.

5 Estamos nos referindo a inspiração para a criação de uma de suas mais célebres obras, a pintura no teto da Capela Sistina, com especial atenção ao detalhe da "Criação do homem". Do alto de uma montanha, Michelângelo tem a "visão" da totalidade de sua obra através da movimentação das nuvens no céu. (No cinema, essa cena foi interpretada por Charlton Heston (Michelangelo) no filme "Agonia e Êxtase", de 1.965 dirigido por Carol Reed). 6 MICHELANGELO - CINQÜENTA POEMAS. Trad.

Mauro Gama. Cotia: Ateliê Editorial, 2007. 
concilia-la com a razão, vendo na natureza o lugar da representação dos símbolos dos designios divinos (FRANCO Jr., 2001, p. 175).

$\mathrm{Na}$ visão contemporânea, Fialho (2011, p.50) diz que dentro da modelagem cognitiva, "sensação é a resposta específica a um estimulo sensorial particular, enquanto percepção é um conjunto de mecanismos de codificação e de coordenação de diferentes sensações elementares, visando um significado". Michael Polanyi (1966) destaca a percepção na construção do conhecimento, sendo a instância primordial do conhecimento tácito ou pessoal, que é tão necessário e legítimo quanto o conhecimento objetivo (LASTRES e ALBAGLI,1999), cujos significados surgem reunindo indícios em nosso próprio corpo ou fora dele (POLANYI, 1969 apud PINTO, 2001).

Em sua dimensão cognitiva, o conhecimento tácito inclui elementos como as intuições, emoções, esquemas, valores, crenças, atitudes, competências modelos mentais e percepções, é aquele que se obtém através da prática (FIALHO, et al. 2006), encontrando-se incorporado nos indivíduos constituindo o filtro através do qual percepcionam a realidade, assim, a percepção é o processo mental que possibilita e amplia a relação do indivíduo com seu entorno.

Neste estudo somos sensibilizados pela obra 'Jogos Infantis' de Pieter Bruegel (fig.1), cujos aspectos simbólico-figurativos e metafóricos são ricos de significação. Concordando com Merleau-Ponty (1994), a obra de arte propõe a experiência da percepção (e da sensação) de modo mais intenso e vibrante e neste sentido, pode ser definida como 'um puro ser de sensações', e assim, tornar-se devir - passagem de um estado não humano no homem (DELEUZE e GUATTARI, 2000).

A teoria adotada corresponde à teoria Semiótica Americana, como proposta por Charles Sanders Peirce (1839-1914) que com sua estrutura lógico-triádica, amplia o campo da análise, atentando para elementos que não se configuram imediatamente nos domínios da linguagem verbal, pois de acordo com os estudos há um campo de significação estético ou tácito, que é determinado pela expressão ou materialidade do sinal, e outro campo simbólico, determinado pela convenção cultural. Antes, porém, de adentrarmos ao campo semiótico, apresentaremos aspectos fundamentais dos estudos sobre a leitura de imagens.

\section{Gestalt - Leitura de Imagens}

A Escola da Gestalt teve origem em Wertheimer em 1910, (em estudos 
realizados por uma escola alemã de psicologia experimental) e desenvolveu a teoria da percepção com base em um complexo método para compreensão da maneira como se estruturam, em nosso cérebro, as formas que percebemos. Estudos neste campo indicam que o cérebro humano tende automaticamente a desmembrar a imagem em diferentes partes, organizando-as de acordo com semelhanças de forma, tamanho, cor, textura etc., para depois as reagrupar a partir de um conjunto gráfico, ou uma arquitetura composta por sete relações através das quais as partes da imagem são arranjadas pela capacidade perceptiva: proximidade, semelhança, direção, pregnância, boa continuidade, fechamento e experiência passada.

A partir desse fenômeno, a Gestalt esclarece como chegamos a compreender aquilo que percebemos, explicando a relação psicológica ou fisiológica da relação sujeito-objeto ${ }^{7}$ e dando respostas a algumas dúvidas que comumente temos, como exemplo, por que algumas formas nos agradam e outras não. Neste aspecto, a percepção é um dos temas centrais dessa teoria, pois experimentos levaram os gestaltistas ao entendimento de que é de suma importância a disposição em que os elementos que compõe o todo são apresentados à percepção. Tais fundamentos permitem decifrar a frase "o todo é diferente da soma das partes", esclarecendo que, a percepção que temos de 'um todo' não é o resultado de um processo de simples adição das partes que o compõem, mas sim, do ponto de vista da percepção do olho humano, do modo como os elementos gráficos são estruturados em nossa mente.

O interesse pelo visual tem levado pesquisadores de diferentes campos científicos à necessidade de utilização de metodologias de alfabetização visual ${ }^{8}$, as quais fornecem um corpo de ideias como organização do pensamento sobre o objeto de estudo quer seja, uma imagem artística, uma fotografia, um sinal gráfico ou até mesmo um sentimento. Estes, somente têm significado quando nos remetem a um esquema cultural, criando possibilidades de interpretação. Como já mencionado, a percepção visual talvez seja o mais importante sentido de interação do homem com o seu entorno, mas por si só não é suficiente para a compreensão do mundo. Estabelecer parâmetros ou pontos de vista, experienciar, vivenciar, imaginar, representar e interpretar atribuindo significados são funções cognitivas, pois, tomado em sua raiz, o termo 'cognicão' - diz respeito aos processos de compreensão; e a coisa ou $7 \quad$ Rudolf Arnheim em seu livro Art and Visual Perception definiu as categorias visuais: equilíbrio, figura, forma, desenvolvimento, espaço, luz, cor, movimento, dinâmica e expressão, como tradutoras da experiência sensível-estética do espectador. No Brasil, Fayga Ostrower $(1983 ; 1987 ; 1990)$ aborda as relações entre os aspectos formais e expressivos das imagens. $8 \quad$ Podemos citar a tendência formalista da leitura de imagens da desenhista Donis Dondis (1997), responsável pela introdução do conceito de alfabetismo visual, seus estudos propõe um sistema básico para a aprendizagem, identificação, criação e compreensão de mensagens visuais com acesso a todo tipo de público. Outras metodologias podem ser lidas em Robert Willian Ott (1984); Abigail Housen (1992); Parsons (1992); Rossi (2003) (SARDELICH, 2006). 
produto é a representação, o significado relativo àquilo que é conhecido.

Considera-se que a leitura visual, especialmente nas imagens artísticas, deve ser iniciada no nível pré-figurativo, este relacionado àquilo que vem antes da forma e antes do conceito já estabelecido por alguém. Diz respeito ao conhecimento primeiro, inacabado, neste sentido, no âmbito da cognição, abrem-se possibilidades de diálogo entre campos de conhecimento, considerando-se o conhecimento estético ou tácito, e os sentidos decorrentes deste tipo de conhecimento no âmbito de primeiridade.

Para Joly (2007), a imagem pode ser também um processo de expressão extremamente rico, inesperado, criativo e mesmo cognitivo, porém, é preciso não esquecer que se toda a imagem é representação, "ou um objeto segundo, em relação a uma outra que ela representaria" (p.14). Concluímos essa seção pontuando o pensamento de Perassi (2005, p.9): "a produção de imagens ou de quaisquer outros tipos de expressão é produção de conhecimento, independente do grau de complexidade ou inovação deste conhecimento".

\section{Fenomenologia Perciana}

Desenvolvida por Charles Sanders Peirce a teoria semiótica abarca seus estudos sobre lógica, ampliando o campo de análise. Ligada à maneira de ver, discriminar e interpretar os fenômenos organiza uma arquitetura triádica em que participam a representação, o objeto e o interpretante. Por seu caráter universal, a semiótica configura-se como "a ciência dos signos e dos processos significativos (semiose) na natureza e na cultura" (NÖTH, 1995, p. 19). Para Santaella (1983), a semiótica é a ciência dos signos, da investigação de todas as linguagens, "a semiótica peirceana é, antes de tudo, uma teoria sígnica do conhecimento, que desenha, num diagrama lógico, a planta de uma nova fundação para se repensar as eternas e imemoriais interrogações acerca da realidade e da verdade" (SANTAELLA,1995, p. 118).

No sentido indicado por Ghizzi et al. (2010,p.2-3), a semiótica peirceana "tende a mostrar a ação dos símbolos - signos genuinamente triádicos, ou seja, aqueles nos quais todos os constituintes estão envolvidos em relação da ordem de terceiridade - dentro de um conjunto significante no qual estão envolvidos ícones e índices". Assim para Peirce, linguagem, percepção e signo são inseparáveis. Só podemos conhecer o mundo através de signos. A própria percepção se dá através de signos.

Santaella (2001, p.14) contribui com a explicitação dos conceitos dizendo 
que todos os processos perceptivos (visuais, auditivos, táteis, olfativos e degustivos) "já funcionam como signos, mas sem deixarem de ser mediatizados pelo equipamento específico do nosso sistema sensório-motor e pelo potencial e limites dos nossos esquemas cognitivos, mentais".

A semiótica peirceana parte da concepção de que a experiência do fenômeno pode ser sempre reduzida de forma a apresentar três tipos de propriedades, também denominadas categorias da consciência: (1) primeiridade; (2) secundidade; (3) terceiridade. A primeiridade trata-se, pois, de uma consciência imediata tal qual é, nenhuma outra coisa senão pura qualidade de ser e de sentir; na secundidade, há um mundo real, reativo, um mundo sensual, independente do pensamento e, no entanto, pensável, é a arena da existência; e por fim, a terceiridade corresponde à camada da inteligibilidade, ou pensamento em signos, através da qual representamos e interpretamos o mundo (SANTAELLA,1983).

Neste sentido, analisando o fenômeno, os sentimentos e sensações são elementos da primeiridade; a relação de continuidade entre os sentimentos de primeiridade com a realidade são elementos da secundidade, já as convenções constituem a terceiridade, ou seja, a teoria Semiótica, parte da sensação (primeiridade) para a realidade física (secundidade), que é igualmente mediada pela cultura (terceiridade). No tocante à comunicação visual, por exemplo, "o primeiro elemento ou representamen é aquilo que é percebido pela visão, como as palavras e as imagens deste artigo. O segundo elemento ou objeto do signo é aquilo que está ausente e é representado pelo signo" (TEIXEIRA et al, 2011, p.104).

Para Peirce (2000), a percepção é entendida como processo privilegiado para integrar as três dimensões de que somos feitos: a sensória; a física e a cognitiva. Assim, um signo (parte sensória da percepção) tem a intenção de representar, ao menos em parte, um objeto (parte física da percepção) que é então, de certa forma, a causa ou determinante do signo, ainda que o signo represente falsamente o objeto. Entretanto, dizer que ele representa seu objeto implica que ele afeta uma mente de tal modo que, de certa maneira, determina, naquela mente, algo que é mediatamente próprio ao objeto (parte cognitiva da percepção) (SANTAELLA, 1983, p. 58).

Seguindo roteiro de Perassi (2008), na primeiridade, as sensações percebidas são denominadas - ícones. Nessa condição, o percebido é um fenômeno fundamentalmente interno à mente. A secundidade é marcada pela consciência dos estímulos que propiciaram as sensações, implicando no reconhecimento de elementos da realidade externa, cuja existência resiste à vontade da mente, como - índices de realidade. A terceiridade abriga os 
fenômenos tipicamente simbólicos, nos quais as sensações são nomeadas e relacionadas como - símbolo. Há uma interposição interpretativa entre a consciência e a coisa que foi percebida, promovendo a mediação entre essa consciência e os fenômenos, pois, os símbolos são mediadores com os quais representamos e interpretamos o mundo (PERASSI, 2008). Ainda para Perassi (2005, p.4), "as inúmeras percepções são registradas na memória de modo consciente ou inconsciente, compondo um acervo de lembranças de sensações, sentimentos e idéias".

São três as categorias da percepção, quais sejam percepto, percipuum e julgamento de percepção. O termo percepto diz respeito ao estímulo, o que se apresenta para ser percebido (aquilo que insiste sobre nossos sentidos, mas nada professa), o termo percipuum refere-se ao modo como o percepto é filtrado pelos sentidos, adquirindo características próprias ao sistema sensório do receptor e traduzido na forma e de acordo com o limite imposto pelos órgãos sensores. Por fim, o julgamento de percepção diz respeito ao modo como o percipuum é imediatamente adquirido e absorvido nos esquemas mentais interpretativos de que o receptor está dotado e neste sentido, ao decifrarmos os sinais, adentramos ao processo da semiose, que é a ação lógica dos signos em que $A$, relacionado à $B$, gera $C$ que contém algo de $A$ (DOMINGOS, 2006).

A ideia de semiose tem a sua origem no radical grego semeiosis e, de acordo com Peirce, refere-se a qualquer tipo de ação do signo, "é a ação de determinar um interpretante" (SANTAELLA, 1992, p.50). Este visto aqui como um signo novo, gerado de um signo anteriormente dado. Semiose representa a ação de um signo ao gerar ou produzir um interpretante de si mesmo. Por isso, nesse nível, ou seja, na semiose, sempre haverá um input, como algo que adentra uma mente, nem sempre dotada de cérebro, uma transformação interior e um output como elemento traduzido, formando assim, o diagrama de base da geração de signos (DOMINGOS, 2006, p.203), como um movimento espiralado, na medida em que toda apreensão sígnica pode tornar-se o reinício de uma nova semiose, o que permite esclarecer o papel desempenhado pela percepção nos processos cognitivos.

Em síntese, ao decifrarmos os sinais, adentramos ao processo de semiose. A partir da emergência dos sistemas audiovisuais a imagem é percebida como objeto de comunicação, como signo informativo-comunicativo, elemento que incorpora códigos. Seguindo definição teórica de Peirce, "a imagem não é todo o ícone, mas é um signo icônico" (JOLY, 2007, p.41), pois neste sentido, parte da realidade física (secundidade) para a sensação (primeiridade) que é mediada pela representação cultural (terceiridade).

Uma leitura de imagem que tem influência dos estudos semióticos enfatiza 
os seguintes códigos: a) espacial - o ponto de vista do qual se contempla a realidade, acima; abaixo - esquerda; direita; b) gestual e cenográfico - sensações que nos produzem os gestos, o vestuário, a maquiagem, o cenário; c) lumínico - fonte de luz e suas variações de forma e volume; d) simbólico - convenções culturais; e) gráfico e d) relacionais, propondo (1) identificar o modo de ser dela própria, suas características qualitativas, independente de qualquer relação de representação; (2) o modo de relação entre a imagem e seus objetos, ou seja, entre a imagem e o que está apta a representar; (3) os modos de relação entre a imagem e seus representantes (interpretações de fato ou potenciais) (GHIZZI, 2003).

A exposição precedente, ainda que sucinta, guia-nos para a análise da imagem em questão, conhecendo o contexto no qual o signo se constitui como uma representação dotada de sentidos.

\section{A Obra, o Artista e o Contexto}

A imagem analisada neste trabalho faz parte da "Coleção de Arte" editada em sua versão brasileira pela Editora Globo em 1997 - prancha 7 e é uma fotografia de pintura feita em prancha de madeira, com as dimensões 118 x 161cm que data de 1560 . Tem como título "Jogos Infantis" do artista Pieter Bruegel e compõe o acervo do Kunsthistorisches Museum em Viena.

Figura 1 - Jogos infantis (1560) de Pieter Bruegel

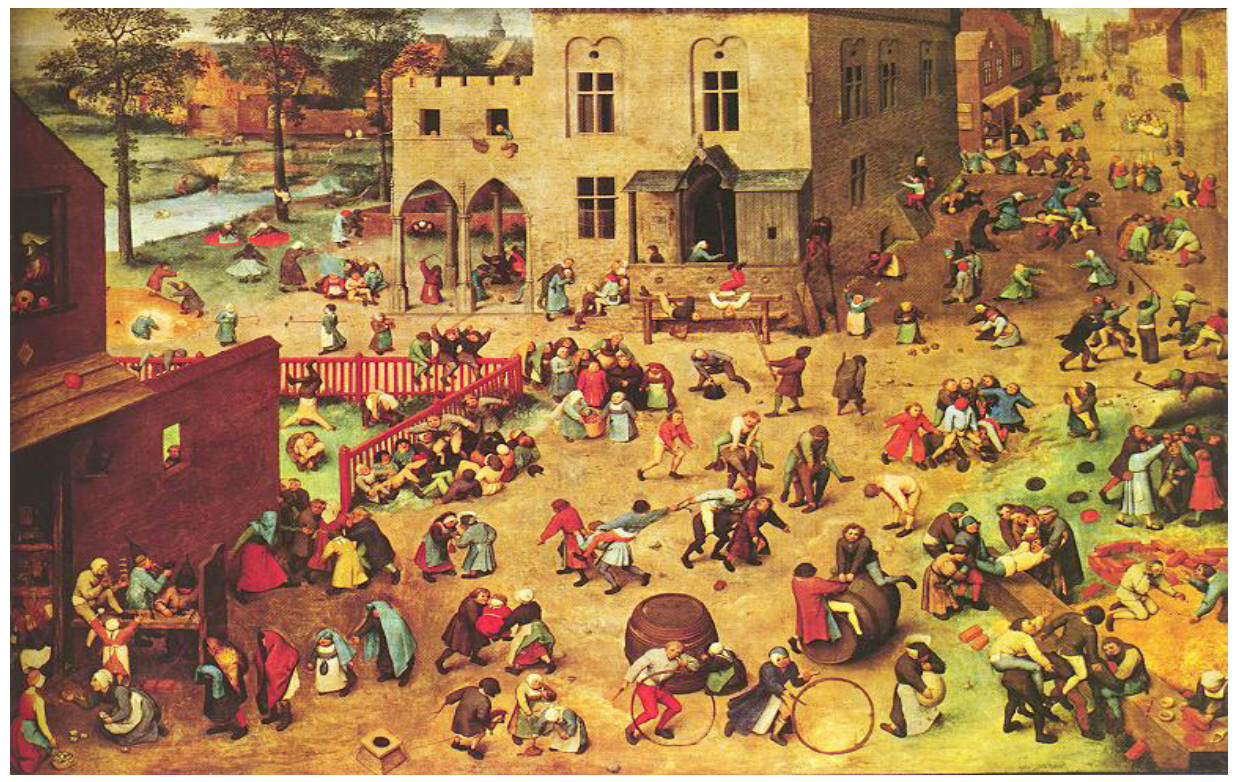

Fonte: Coleção de Arte (Editora Globo, 1997). 
A fim de contextualizar seu percurso, faremos uso do traçado histórico e sociocultural construído por Baumann $(1997)^{9}$, que indica que o autor da obra original, Pieter Bruegel nasceu aproximadamente em 1525, em Breda, no Brabante setentrional (atualmente compreendido na Holanda), viveu em Antuérpia, centro de "liberdade de pensamento" até 1563 convivendo com filósofos e artistas, possuía boas relações de amizade, tendo sido protegido do Cardeal Granvelle, um religioso amante das artes "um convívio que demonstra a sua sofisticação cultural e a possibilidade de um questionamento em relação à influência religiosa (a inquisição local era extremamente severa) e à dominação espanhola". Em 5 de setembro de 1569, retira-se para Bruxelas (BAUMANN,1997, p.73).

Durante o período chamado de Idade Média $^{10}$ até o Renascimento ${ }^{11}$, as realizações e invenções dos artistas italianos e as novas formas de representação propagaram-se por todo o continente, atraindo a atenção dos artistas do norte da Europa pelas produções dos artistas florentinos e venezianos. Pieter Bruegel foi um deles. Entretanto, a arte dos Países Baixos, especialmente a pintura em Flanders, país protestante da Europa que hoje corresponde à Holanda e à Bélgica, manteve-se mais próxima às fontes populares, apresentando sobretudo cenas inspiradas na vida cotidiana, que anos depois foram conhecidas como pintura de gênero ${ }^{12}$.

Baumann (1997, p.76) citando Tolnay (1954), argumenta que "por suas soluções decorativas, pela abundância de motivos Bruegel 'toca' ainda a Idade Média". Concordando, Guimarães (2007, p. 3) cita que o artista viveu uma fase de mudanças significativas para as imagens, pois no auge do Renascimento, "período marcado pela adoção da perspectiva com suas leis de proporcionalidade, da apologia à razão, da perspectiva como índice, ele realiza uma obra com características medievais".

$9 \quad$ Mestre em História Social e Doutora em História Social das Ideias (Universidade Federal Fluminense).

10 É como foi denominado o período situado entre a queda do Império Romano do Ocidente (no século V) - pelas invasões bárbaras - e o declínio do Império Romano do Oriente (século XV) - com a tomada de Constantinopla. Foi uma época dominada pelo sistema de produção feudal, no qual os donos de terras se tornaram poderosos, descentralizando o controle estatal. As terras eram cedidas aos camponeses em troca de proteção militar contra os bárbaros, cobrando fidelidade absoluta, além de uma parte da produção. Neste período, a Igreja Católica se fortaleceu como instituição de fé.

11 O termo Renascimento, ou Renascença, faz referência a um movimento intelectual e artístico surgido na Itália, entre os séculos XIV e XVI, difundido por toda a Europa. A concepção medieval do mundo se contrapõe uma nova visão, empírica e científica, do homem e da natureza.

12 De acordo com Gombrich (1999, p. 381), "pintura de gênero" é designada pela expressão francesa peinture de genre. No Renascimento, "a questão da separação entre representação religiosa e representação profana estará na origem do surgimento dos gêneros pictóricos" (JOLY, 2007, p.19). 
Para Hauser (1982) as obras de Bruegel tiveram origem na curiosidade da aristocracia, pois segundo esse autor, "as classes oprimidas e que lutam pela sua ascensão social, desejam ver a representação de condições de vida que encaram como um ideal a atingir, mas não a espécie de condições de que estão tentando libertar-se". O artista atende a um determinado grupo social que deseja conhecer a realidade dos camponeses. "A vida da gente simples do campo e da classe trabalhadora foi considerada (...) como uma curiosidade, qualquer coisa de estranho e de exótico (...)" (HAUSER, 1982, p.525).

A obra de Bruegel simplificou a realidade mostrando a tragédia e a sabedoria de fundo popular em uma obra que mistura a técnica flamenga, sua herança nativa e elementos renascentistas, oriundos de seus estudos com artistas italianos. Em seus desenhos, gravuras e pinturas, Bruegel retrata o mundo das pequenas aldeias rurais e a cultura medieval, as multidões coloridas, os camponeses em suas atividades cotidianas. Sua obra pode ser lida como um testemunho de um mundo que comporta o real e o fantástico. Elemento essencial nas suas pinturas, o misticismo mostra-se em meio a elementos naturais e suas figuras humanas não mostram nem bravura, nem sutileza, transparecem uma visão crítica e reveladora acerca do homem, do mundo e da sociedade de sua época. Hagen e Hagen (1995) ressaltam que os pintores europeus do século de Bruegel inspiravam-se, muitas vezes, em temas religiosos e antigos em cenas bíblicas e fatos com heróis e deuses greco-romanos, com atenção especial à beleza do corpo humano. Os pintores flamengos, porém, não pintaram os ricos e poderosos, mas as pessoas anônimas, os camponeses, os trabalhadores rurais, os artesãos, suas moradias e suas aldeias.

Outro fator que sugere reflexão nas obras de Bruegel é sua função moral. Hagen e Hagen (1995, p. 50) discutem se teria sido Bruegel, em primeiro lugar, um "moralista popular", já que em suas obras encontram-se mensagens didáticas, proporcionando a cada quadro ser visto como uma obra de moralização. Entretanto, Souza (2005, p.23) pontua: "observando os elementos paisagísticos e humanos presentes nas telas de Bruegel compreende-se o apelo não necessariamente moralista para uma vida sem guerras, pacífica e farta". Conclui dizendo que suas representações de camponeses ou de paisagens não são artificiais, mas "denotam o clamor pela naturalidade e para um lugar específico para a fé".

Descrito por Pizzo (1997, p.8) como sendo "o único quadro em que Bruegel pintou sem pôr em cena um subentendido qualquer ou uma simples alusão à moralidade humana", também pode ter sido o início de uma série de outras pinturas que representariam as diversas idades do homem, pois segundo a concepção clássica da Antiguidade, o homem é um microcosmo, não apenas um fragmento do todo. Nele encontram-se 
os quatro elementos constitutivos do mundo, terra, fogo, agua e ar, e cada parte de seu corpo corresponde a uma parte do universo: a cabeça ao céu, o peito ao ar, o ventre ao mar, as pernas a terra, os ossos às pedras, as veias aos galhos de árvores, os cabeços às ervas, os sentidos aos animais. As etapas de sua vida são seis: infância, adolescência, juventude, maturidade, velhice e decrepitude (FRANCO Jr.,1992). De qualquer forma, o suposto objetivo de Bruegel parece não ter sido levado adiante, pois não há na literatura menção a outras obras referentes à temática. Para Hagen e Hagen (1995) a obra de Bruegel é um aviso aos adultos para que não desperdiçassem a vida como se fosse uma brincadeira de criança e se caracteriza como um registro da passagem da infância à fase adulta.

\section{Descrição e leitura estética da obra "JOGOS INFANTIS"}

Em um plano levemente inclinado, de uma cor terrosa, cerca de 200 pessoas, homens e mulheres, com diferentes idades praticam ações típicas de jogos e de brincadeiras infantis, pião, boneca de madeira, jogo de bola, perna-de-pau, acrobacias e malabarismos, sete marias, cavalo de pau, corredor polonês, rodas, pula-cabra, cabo de guerra, entre as mais de 80 atividades. O cenário representa uma aldeia rural e as pessoas vestemse de forma aparentemente igual, diferenciando-se pelo tamanho e cores das roupas de feitio simples, calças, casacos, mantos, saias rodadas na cor vermelha; vestidos, calças colantes e camisas amarelas; toda sorte de modelos em tons de marrom e a curiosa predominância dos tons azuis em casacos, vestidos, lenços e aventais.

Os movimentos físicos são inquietos, mas não há em suas aparências o riso ou o cansaço, apenas rostos muito semelhantes. A esquerda da obra há pessoas nuas tomando banho em um rio margeado com grama verde, arbustos e árvores que demonstram um viço e frescor natural, contrastando com o solo árido e empoeirado onde as atividades ou jogos acontecem. $\mathrm{Na}$ extremidade direita há uma rua em aclive, com intensa movimentação de pessoas em perspectiva, dando continuidade às atividades que estão por toda obra.

As atividades se desenvolvem em um espaço público, numa área aberta, rodeada por construções, como num vilarejo. A edificação que está localizada pouco acima do centro da obra, representa uma construção em tijolo, com altura de cerca de 2 a 3 andares, possui um espaço aberto ladeado por colunas com formato ogival ${ }^{13}$, uma espécie de pátio coberto 13 Característica da arquitetura gótica, o arco ogival criou a possibilidade 
onde crianças jogam pião. Há também uma lateral com um pórtico com diversos detalhes e recortes em madeira rústica, e em seus degraus, feitos igualmente de tijolo, pessoas sentadas assistem a uma demonstração física de dois homens adultos (um está suspenso nas costas do outro).

A esquerda inferior da obra há uma edificação feita em tijolos marrom escuro, com detalhes nos umbrais das janelas e uma cobertura, espécie de toldo em madeira. Há indícios de ser uma casa de comércio, pois através da porta aberta é possível identificar prateleiras de exposição de produtos. Esta ainda comporta um espaço externo de grama verde, delimitado por uma cerca de madeira na cor vermelha. Neste espaço há crianças desenvolvendo atividades acrobáticas como cambalhotas e piruetas, alguns meninos estão 'empuleirados' na cerca, como se estivessem cavalgando.

No lado externo da cerca, já na larga rua é possível ver uma turma de meninas guiadas por uma mulher adulta que parece as conduzir e as proteger, pois estão muito próximas umas das outras como em uma procissão ou cortejo. Duas meninas à frente carregam uma grande e pesada cesta de palha que parece estar cheia de alimentos, provavelmente frutas, indícios de uma atividade de entretenimento e recreação com realização de uma refeição coletiva ao ar livre.

O excesso de elementos e de linhas faz da análise um exercício com alto grau de complexidade. $\mathrm{O}$ artista não compõe a partir da perspectiva ${ }^{14}$ italiana $^{15}$, mas utiliza os referenciais próprios da ilustração medieval em que o plano empregado parte da visão aérea do espectador. "O caráter particular da pintura é alcançado pelo contraste entre linhas rígidas da cena e os movimentos quase instantâneos dos personagens colocados no plano levemente inclinado da aldeia. Um recurso comum às ilustrações medievais"

de se construir igrejas mais altas. Além disso, o desenho da ogiva, que se alonga e aponta para o alto, acentua a impressão de altura e verticalidade. Outro recurso arquitetônico usado no estilo gótico foram os pilares, dispostos em espaços bem regulares e chamados de chevet. Com esses suportes, o edifício não precisa forçosamente de grossas paredes para sustentar sua estrutura.

14 Perspectiva é uma palavra latina que significa "ver através de" onde somos levados a acreditar que olhamos para um espaço através de uma "janela" e se reinterpreta como um plano do quadro. Sobre este plano do quadro projeta-se o contínuo espacial visto através dele e no qual se considera "estarem projetados" os diversos objetos (PANOFSKY,1999, p.31). 15 A construção de um espaço geométrico racional, ou seja, infinito, constante e homogêneo. Com o tratado De Pittura, Alberti vem afirmar que a perspectiva é uma ciência e que não é mais do que a intersecção da pirâmide visual, segundo uma distância e um corpo fixado ao centro. Este conceito reforça e propagandia o centralismo das pinturas do Renascimento italiano, com o posicionamento do ponto de fuga no centro da composição, ao contrário da pintura Flamenga do mesmo período que coloca a maior parte das vezes o ponto de fuga descentrado na composição. Alberti (aplicando os conhecimentos com as teorias de Euclides e Tales) diz que os nossos olhos funcionam como uma pirâmide triangular, onde a base é a quantidade de coisa vista e cujos lados são esses mesmos raios que se dirigem ao olho desde os pontos extremos da forma quantificável (TRINDADE, 2008, p.119). 
(BAUMANN, 1997, p.76). Ao observarmos a obra não nos sentimos "dentro", mas como observadores aéreos do espaço de movimentação. Como bem acentuam Hagen e Hagen (1995) a obra de Bruegel representa um enigma, que o espectador é instigado a decifrar.

Enquanto os artistas renascentistas da Itália usavam a paisagem como um pano de fundo para a cena principal, Bruegel fazia o contrário, para ele a paisagem era tão importante quanto os outros personagens. $O$ artista a descreve procurando aproximá-la a realidade, evitando alterar o que via na natureza, ao contrário dos artistas italianos que buscavam também na paisagem, equilíbrio e harmonia. Para Argan (2001) Bruegel inverteu o processo de alegorismo italiano, ou seja, se para os italianos a ideia dava forma à imagem, para Bruegel, a imagem compunha a ideia.

\section{Interpretações Simbólicas}

Como representação, a imagem é um signo, portanto, composto pela tríade representamen, objeto e interpretante. Assim, considerando a teoria peirceana, a fotografia da obra Jogos Infantis é um signo que representa um objeto; este símbolo representa a ideia de jogos infantis, bem como um conjunto de jogos praticados por indivíduos numa fase da vida denominada infância.

A imagem fotográfica do quadro em estudo (Fig. 01) oferece um conjunto de sensações coloridas produzindo afetos específicos. Esse conjunto de sensações é promovido pela luminosidade física e constitui o fenômeno de secundidade. Esta categoria pretende enunciar às reflexões que podem dar prosseguimento ao roteiro de análise, e por seguinte, à categoria da terceiridade, ou seja, a ideia de que se trata de um grande e variado conjunto de pessoas brincando nas ruas de uma antiga cidade é um fenômeno imaginativo-cognitivo.

Quanto à técnica usada na reprodução da imagem, é válido registrar que Santaella $(1983$, p.15) define a fotografia como um signo híbrido que contém ícones (semelhança) e índices (continuidade), estando ligado à categoria primeiridade, pois estes se relacionam com seus referentes de modo analógico ou apenas sensível. Então podemos dizer que as cores das formas (produzidas pela tinta no suporte), a luminosidade (tanto referente às cores como as produzidas pela técnica fotográfica) e a textura (resultado do contato da tinta com o suporte usado, neste caso, a madeira) também estão incluídas nesta categoria.

Prosseguindo a análise, podemos citar a indicação de um processo de 
semiose caracterizado pelo signo linguístico "Jogos Infantis", título da obra. As brincadeiras são facilmente identificadas e permitem a relação com atividades ainda presentes na infância contemporânea. Esse elemento representa a categoria terceiridade, pois há no espectador a identificação com significados do universo simbólico cultural. Os termos jogos e brincadeiras contém forte referência ao período de infância do adulto com representações veiculadas pela memória e imaginação. A descrição de um sentimento exige do leitor o uso da memória em busca de um sentimento semelhante vivenciado no passado, e este processo por sua vez, já é um aspecto da secundidade (PEIRCE, 2000, p. 15). A terceiridade abriga os fenômenos tipicamente simbólicos, nos quais as sensações são nomeadas e relacionadas como símbolos, pois os símbolos são mediadores com os quais representamos e interpretamos o mundo (PERASSI, 2008).

Argan (2001) situa a obra de Bruegel como uma sucessão de imagens, cíclica e ilimitada, que causa estímulos através do lúdico e da curiosidade provocada. O cenário é constituído por elementos paradoxais: aldeia rural presumivelmente existente na época que, por suas características fixam uma data ou período e elementos humanos e objetos que podem ser identificados por qualquer um, sem necessariamente representar um vínculo histórico específico.

Porém é válido ressaltar que o conjunto da obra nos remete à interpretação das representações da vida rural na era medieval e curiosamente, alguns signos sugerem situações da urbanidade do campo (BURKE, 2004, p.172), como por exemplo, os trajes das crianças são indícios de que elas eram tratadas como adultos pequenos, "os vestidos, os aventais e os tocados das meninas eram parecidos com os das mães e os calções, os gibões e as cotas dos rapazinhos eram idênticos aos pais" (HAGEN e HAGEN,1995, p.31).

Por fim, é possível categorizá-la como uma alegoria, que pode, certamente, remeter a muitas significações, mas enquanto signo, uma expressão do que está socialmente convencionada, a alegoria nos remete a um universo de significações, com estreita interação com o espectador que sensorialmente, desvela o que está oculto e, especificamente na obra em estudo, o universo alegórico de tradição nos remete-nos à cultura popular, situada na categoria terceiridade.

\section{CONSIDERAC̣ÕES FINAIS}


$\mathrm{Na}$ obra de arte estão contidos ícones e índices, qualidades e reações que produzem interpretações do mundo. Como lógica expressiva, a arte tem, portanto, um status de terceiridade, pois enquanto signo consiste num símbolo que justifica outro símbolo. Eis portanto, novamente, o pensamento de $\mathrm{S}$. Tomas de Aquino: "Para pensar, servimo-nos de imagens, não algumas vezes, ocasionalmente, mas sempre e normalmente" (HUGON,1998, p.161).

Tendo como parâmetros de estudo os conceitos da teoria semiótica de Charles Peirce, procurou-se analisar a imagem como processo de significação ou semiose, pois de acordo com os autores citados neste trabalho, os fenômenos acontecem na mente como produtos da percepção e a consciência é o lugar onde ocorrem as sensações, os sentimentos, a cognição. A partir do exposto, a categoria primeiridade refere-se a todo aspecto de qualidade que se vivencia nessa experiência, a secundidade é a reflexão envolvida nesse processo e a terceiridade é a representação que se fará. Assim, a apreensão de determinado conceito teórico (e não sua simples enunciação das mesmas ideias) envolve necessariamente a passagem por essas três categorias e, a partir do momento em que o receptor reconhece qualquer aspecto narrativo de uma imagem, ele já está agindo sob o campo da terceiridade. 


\section{REFERÊNCIAS}

ARGAN, Giulio Carlo. Clássico Anticlássico - O Renascimento de Brunelleschi e Bruegel. São Paulo: Companhia das Letras, 2001.

BAUMANN, Thereza de B. Da Iconografia, Da loucura, Da história. Revista de História Regional. Universidade Estadual de Ponta Grossa. Revista de História Regional, Departamento de História da UEPG, vol.2, n.1,1997, p.69-113.

BURKE, Peter. Testemunha ocular. História e Imagem. Bauru, SP: EDUSP, 2004.

DELEUZE, Gilles; GUATTARI, Félix. O que é a filosofia? Trad. de Bento Prado Jr., Alberto Alonso Muñoz. Rio de Janeiro: Ed. 34, 2000.

DOMINGOS, Adenil Alfeu. O processo de semiose no não verbal. Departamento de Comunicação Social - Universidade Estadual de São Paulo (UNESP). Bauru, SP. Estudos Lingüísticos, XXXV, p. 201-208, 2006.

FIALHO, Francisco Antonio Pereira. Psicologia das atividades mentais: Introdução às ciências da cognição. Florianópolis: Insular, 2011.

; MACEDO, Marcelo; SANTOS, Neri dos; MITIDIERI, Tibério da Costa. Gestão do conhecimento e aprendizagem: as estratégias competitivas da sociedade pós- industrial. Florianópolis: Visual Books, 2006.

FRANCO JR., Hilário. A Idade Média; nascimento do Ocidente. 2ª ed. rev. e ampl. São Paulo: Brasiliense, 2001.

GHIZZI, Eloisa Bortolotto. Leitura como descoberta e criação de mundos. São Paulo: PUC, 2003.

; MACHADO, Amanda Pires; SOUSA, Richard Perassi Luiz de. Ícones, índices e símbolos em um trecho de O nome da rosa. Semeiosis: Semiótica e transdisciplinaridade em revista. [suporte eletrônico] Disponível: http://www.semeiosis.com.br/o-nome-da-rosa/. Acesso em $11 / 11 / 2011$.

GUIMARÃES, Andressa Fabiana. As relações interartes em José Saramago e Ernesto Sábato. Encontro Regional da ABRALIC 2007 Literaturas, Artes, Saberes. 23 a 25 de julho de 2007. (FFLCH/USP). São 
Paulo, p.1-16.

HAGEN, Rainer; HAGEN, Rose Marie. Pieter Bruegel, o Velho. Cerca de 1525-1569-Camponeses, loucos e demônios. Benedikt Taschen, 1995.

HAUSER, Arnold. História Social da Literatura e da Arte. São Paulo: Mestre Jou, 1982.

HUGON, Pde Edouard. Os princípios da Filosofia de São Tomás de Aquino : as vinte e quatro teses fundamentais. Trad. Odila Moura. Porto Alegre: EDIPUCRS, 1998.

JOLY, Martine. Introdução à análise da imagem.11a ed. Campinas, SP: Papirus, 2007. Disponível: http://books.google.com.br/books. Acesso em 02/12/2011.

LASTRES, Helena ; ALBAGLI, Sarita. Informação e globalização na era do conhecimento. Rio de Janeiro: Campus, 1999.

MERLEAU-PONTY, Maurice. Fenomenologia da percepção. Trad. C. Moura. São Paulo: Martins Fontes, 1994.

NÖTH, Winfried. Panorama da semiótica: de Platão a Peirce. São Paulo: Annablume, 1995.

PANOFSKY, Erwin. A perspectiva como forma simbólica, Lisboa, Ed. 70, 1999.

PEIRCE, Charles Sander. Semiótica. Trad. José T. C. Neto. 3a ed. São Paulo: Perspectiva, 2000.

PERASSI, Richard Souza. Roteiro didático da arte na produção do conhecimento. Campo Grande - MS: EDUFMS, 2005.

. Semiótica. Florianópolis: UFSC, 2008.

Teoria da forma. Florianópolis: UFSC, 2008.

PINTO, André Moreira. A Importância das contribuições de PIAGET E POLANYI em Gestão do conhecimento e aproximações na perspectiva organizacional. In: SEMINÁRIO CATARINENSE DE GESTÃO DO CONHECIMENTO E DA TECNOLOGIA, 2001. Florianópolis. Anais... 
PIZZO, Esnider. Brueghel. Coleção de Arte. Trad. Lauro Machado Coelho. São Paulo: Ed. Globo, 1997.

SANTAELLA, Lucia. A assinatura das coisas. Rio de Janeiro: Imago,1992.

A teoria geral dos signos: semiose e autogeração. São Paulo: Ática,1995.

. Matrizes da linguagem e pensamento: sonora, visual e verbal. Iluminuras/FAPESP. São Paulo, 2001.

. O que é semiótica. Coleção Primeiros Passos (103). São Paulo: Brasiliense, 1983.

SARDELICH, Maria Emilia. Leitura de Imagens e cultura visual; desenredando conceitos para a prática educativa. Educar. Curitiba. n.27 Editora UFPR, 2006. p.203-219.

SOUZA, José Fernando Rodrigues de. A loucura na renascença: análise comparativa das obras de Erasmo e Bruegel, na perspectiva de Foucault. Perspectivas, Campo dos Goytacazes-RJ, v.4, n.7, jan/jul 2005.p.19-29

TEIXEIRA, Julio Monteiro; MATOS, Luana Marinho; PERASSI, Richard Souza. Análise semiótica da imagem de uma cadeira. Estudos Semióticos.[on-line], v. 7, n. 2, São Paulo, novembro de 2011, p. 102109. Disponível: http://www.fflch.usp.br/dl/semiotica. Acesso em 27/01/2013.

TRINDADE, Antonio. Um olhar sobre a perspectiva linear em Portugal, nas pinturas de cavalete, tectos e abóbadas: 1470-1816. Dissertação de Doutoramento em Belas Artes, especialidade em Geometria Descritiva, Faculdade de Belas-Artes da Universidade de Lisboa, 2008, p. 118-122.

Recebido em:21/03/2013.

Aceito em: 29/04/2013. 